\title{
A Re-examination of the MM Capital Structure Irrelevance Theorem:
}

\section{A Partial Payout Approach}

\author{
Kouki Mondher \\ Faculty of Management and Economics Sciences of Tunis, Tunisia \\ Tel: 216-98-543-763Ｅ-mail: koukimondher@yahoo.fr
}

Received: April 11, $2011 \quad$ Accepted: May 23, $2011 \quad$ Published: October 1, 2011
doi:10.5539/ijbm.v6n10p193 $\quad$ URL: http://dx.doi.org/10.5539/ijbm.v6n10p193

\begin{abstract}
Contrary to Modigliani and Miller (1958, MM hereafter), Capital Structure is not irrelevant when we consider a firm with a dividend payout policy. This article extends the MM capital structure theorem by relaxing the full payout assumption and introducing retention policy. The theoretical contribution shows that it is possible to verify the theorem when we suppose an investor who exchanges his initial holding for another portfolio composed of consumption and investment. The empirical analysis of this new approach is based on a data set of the USA Electric Utilities and Oil companies for the period 1990-1998. The results show that the relationships between leverage and firm value are significantly affected by the firm's payout ratio. This finding is largely inconsistent with MM's view that the division of a stream between cash dividend and retained earnings is a mere detail in dealing with the irrelevance of capital structure.
\end{abstract}

Keywords: Capital structure, Firm value, Irrelevance theorem, Arbitrage, Payout policy

\section{Introduction}

Miller and Modigliani's (1958) irrelevance theorem is one of the important and puzzling issues in modern corporate finance theory (note 1), which has challenged the traditional view that an optimum leverage exists. The main source of the puzzle stems from the fact that financial research don't seem to explain the firm financing behaviour as we attempt to reconcile the MM theory with the evidence(Myers 1984, Gordon and Chamberlin1994, Rajan and Zingales1995). The MM theorem(proposition I) has shown that under a perfect market hypothesis the market value of any firm is independent of its capital structure (Stulz 2006). This fundamental proposition explicitly indicates that the aptitude of investors to engage in personal or "homemade" leverage is sufficient to ensure that corporate leverage in itself cannot modify the total market value of the firm. In other words, the theorem provides conditions under which arbitrage by individuals keeps the value of the firm depending only on cash flow generated by the investment policy.

Following the seminal paper of MM (1958), most theories have been put forward in corporate finance to reconcile the shortcomings of the irrelevance theorem with variables that explain the firm's choice of capital structure. According to the previous debate, criticism against this theorem can be grouped in two types of arguments: on the one hand, there are papers which deal with the limitations of the arbitrage conditions; on the other hand, there are studies which analyze the effect of market imperfections on the firm's choice of capital structure. Despite the importance of these investigations, we note that all of the limitations deal with the explicit assumptions used by MM, but none deals with the critiques of the MM's implicit assumptions. More recently, DeAngelo and DeAngelo (2006, DD hereafter) have challenged MM's irrelevance dividend policy. Dealing with this alternative of earnings as fully distributed, these authors have shown the irrelevance of the MM dividend irrelevance theorem when MM's assumptions are relaxed to allow retention (note 2). According to $\mathrm{DD}(2006)$, the MM's irrelevance theorem forces firms to choose only among dividend policies that distribute the full present value of free cash flow(FCF) to shareholders. Distributions below the totality of earnings are ruled out by the implicit hypothesis.

Dealing with this problem of fully-distributed earnings, $\operatorname{MM(1958)~used~the~same~hypothesis~in~the~development~}$ of the irrelevance of capital structure. As pointed by the authors "....as will become clear later, as long as management is presumed to be acting in the best interests of the stockholders, retained earnings can be regarded 
as equivalent to a fully subscribed, pre-emptive issue of common stock. Hence, for present purposes, the division of the stream between cash dividends and retained earnings in any period is a mere detail." MM, $1958 \mathrm{p} 266$. However, $\operatorname{MM}(1958)$ failed to recognize that proposition I implies that firms distribute all their cash flow to shareholders without paying any attention to their retention policy. This paper constitutes a new extended proof of the MM theorem by not considering the hypothesis of earnings as fully distributed. We will show that it is possible to verify the theorem when we suppose an investor who exchanges his initial holding for a mix of consumption and investment. The rest of the paper is organized as follows: in the next section, we demonstrate the irrelevance of the MM's capital structure irrelevance when earnings are not fully distributed. We propose the possibility of extending of the MM theorem. Furthermore, we show that the two firms are not forced to distribute their full earnings; and the irrelevance is hold in the presence of the mix of investment and consumption. Section 3 describes the data set, introduces the methodology, examines the hypothesis of the variables and investigates whether the empirical Modigliani-Miller capital structure irrelevance is influenced by dividend payout ratio. Section 4 provides some concluding remarks.

\section{The Theoretical finding}

\subsection{Related literature}

Literature about the validity of the MM-proposition is discussed about whether investors can really accomplish the required conditions of the arbitrage method without changing the overall value of the company. In this context, many authors have shown the inadequacy of the theorem when variables that deal with the real world are introduced. Following Stiglitz(1988), Ross(1988), it is not easy to compare between corporate debt and personal leverage for many reasons: (i) firms can borrow for a long horizon while the investor use short debt to meet shortage of liquidity. (ii) For many individuals' investing in shares is not the only option to fructify money. Investors can use Treasury bills, saving account, and other risk free bonds.

Based on corporate finance literature, Gordon and Chamberlin (1994) focused on how specific market imperfections (cf. tax system, agency and bankruptcy costs) can violate the MM theorem and make significant effect of leverage on the firm value. According to Chang (2004), the MM's first theorem can be verified in an environment where there is no financial market for lending and borrowing, and does not require that investors and companies use the same rate of interest. Bailey (2010) shows how the MM-theorem can be demonstrated when capital market is perfect. If an investor is to duplicate the effects of economic behaviour taken by corporation, he must be able to borrow or lend on the same conditions as the firm. According to Bailey, what really matters is not that taxes are neutral but the rate of taxation is the same. Thus, the MM's irrelevance theorem does not necessarily fail when taxes differ among financial structure and income source.

In addition to these developments, it is well-known that financing decisions in a prefect market present an idealized picture of the firm behavior. We know that none of the MM's assumptions hold in the real world. However, this theorem makes a fundamental contribution to modern theory of corporate finance; it constitutes one of the earliest formulations of the law of one price. In particular, by relaxing MM's assumptions, the theorem provides conditions under which the allocation of capital between equity and debt affects the firm market value. In other words, the analysis of the relevant MM's hypothesis allows us to know which market imperfections explain the real relationship between leverage and the market value of the firm.

\subsection{The failure of the MM theorem when earnings are not fully distributed}

As indicated by Rubinstein (2003), "the law of the conservation of investment value" of MM (1958) was anticipated by many studies (Fisher (1930), Williams (1938), Durand (1952); Morton (1954) for examples) but none of these authors have used arbitrage mechanism to prove the invariance of the cost of capital under changes in leverage. The MM's theorem demonstrates that under certain hypothesis of market conditions, the value of the firm is independent of its debt-equity ratio and is given by capitalizing the expected return generated by its assets. This model can be expressed as:

$$
V_{j}=\left(S_{j}+D_{j}\right)=\frac{X_{j}}{\rho_{k}} \quad \text { for any firm } \mathrm{j} \text { in class } \mathrm{k}
$$

Where V stands for the market value of the firm, $S_{j}$ for the market value of its common shares, $D_{j}$ for the market value of its debts, $X_{j}$ for its expected earnings before interest on its assets, $\rho_{k}$ for the capitalization rate "appropriate to its class k". The analysis of the MM's arbitrage steps shows the implicit hypothesis of full payout ratio which plays a crucial role in the model. The MM's capital structure irrelevance theorem constrains 
firms to distribute all of their earnings. In particular, we note that the validity of the proof developed by MM is based on this implicit assumption. MM(1958) consider (see MM(1958) pages 269-270) the return of the investor $\mathrm{Y}$ as a fraction $\alpha$ of the net income available ( $X-r D$ for levered firm and $X$ for unlevered firm) for the stockholders.

$$
Y_{b}=\left\{\begin{array}{c}
\alpha(X-r D) \quad \text { if } V_{L} \succ V_{U} \\
\alpha X \quad \text { if } V_{U} \succ V_{L}
\end{array}\right.
$$

Where: $Y_{b}$ is the return of the investor before arbitrage process, $\mathrm{L}$ is levered firm and $\mathrm{U}$ is Unlevred firm and $\alpha$ is fraction of the total outstanding shares owned by the investor. Obviously, $\operatorname{MM}(1958)$ confuse artificially return of the investor(dividend return) and net income which should be distributed between dividend and retention. $\mathrm{MM}(1958$ page 266) assert that "the division of the stream between cash dividends and retained earnings in any period is a mere detail".

When we derive the MM capital structure theorem for firms that are not distributing all their earnings as dividends, it follows a non-adequacy of the arbitrage operations, a non-proof of the irrelevance model. Table 1 shows the two cases used by MM(1958) when we introduce a level of payout different from $100 \%$. Therefore, when we use the same arbitrage as $\operatorname{MM}(1958)$, we must then admit that the two firms distribute all the available income to verify the leverage irrelevance proposition.

\section{[Insert Table 1 here]}

As will be shown later, this assumption can modify the validity of the MM theorem. To justify this thesis, we suppose the same steps of the MM first proposition but with a slight difference: here we suppose that firms are not constrained to distribute all of their earnings. This means that we introduce in the arbitrage reasoning the payout ratio (PR) as a new variable. Table 1 below shows that MM theorem is not verified. The difference between returns (before and after arbitrage operations) is not the same as showed by MM (1958 page 270).

\subsection{How do we reconcile MM's capital structure irrelevant theorem with the firm's payout choice?}

The object of this section is to show that it is possible to demonstrate MM's proposition I without the hypothesis of earnings are fully distributed. In other words, we present an extension of the MM capital structure theorem for the case in which firms are allowed to have a payout policy.

To prove this new proposition, we suppose the same hypothesis used by MM (1958), except that earnings are not fully distributed. Using the MM formulation, we consider two firms $(U, L)$ for which the expected return is the same $X_{L}=X_{U}=X$. Company $U$ is financed entirely by stock $S_{U}$ and company $L$ by stock $S_{L}$ and debt $D$. The market value of each firm is then $\mathrm{V}_{\mathrm{U}}=\mathrm{S}_{\mathrm{U}}$ and $\mathrm{V}_{\mathrm{L}}=\mathrm{S}_{\mathrm{L}}+\mathrm{D}$.

* Case 1: we suppose the value of the levered firm $V_{L}$, to be greater than that of the Unlevered firm $\left.V_{U}\right)$.

We denote respectively, $\mathrm{PR}_{\mathrm{L}}$ and $\mathrm{PR}_{\mathrm{U}}$ the payout ratios of the levered and unlevered firms (MM 1958 page 269 suppose $\mathrm{PR}_{\mathrm{L}}=\mathrm{PR}_{\mathrm{U}}=100 \%$ all expected return is distributed).

- First stage (initial return): Consider an investor who owns $\mathrm{s}_{\mathrm{L}}$ dollars' worth of the stock in the company $\mathrm{L}$ representing a fraction $\alpha$ of the total outstanding shares $\mathrm{S}_{\mathrm{L}}$, where $\mathrm{s}_{\mathrm{L}}=\alpha \mathrm{S}_{\mathrm{L}}$. His return $\mathrm{Y}_{\mathrm{L}}$ can be written as:

$$
Y_{L}=\alpha P R_{L}(X-r D)
$$

The return from this portfolio, denoted by $\mathrm{Y}_{\mathrm{L}}$, will be a fraction $\alpha$ of the income distributed $P R_{L}(X-r D)$ for the stockholders of company $\mathrm{L}$, which equals the multiplication of the payout ratio $\mathrm{PR}_{\mathrm{L}}$ by the difference between to total return $X$ and the interest charge $r D_{L}$. Where, $r$ is the interest rate which the firm pays on its debt.

- Second Stage (Arbitrage process): now suppose that an individual investor who adjusts his own personal leverage in order to increase his profits. He makes the following operations:

- (a ) Sold his worth $\mathrm{s}_{\mathrm{L}}$ of the company $\mathrm{L}$ and he divided it as follows: (i) he partially invested an amount $\mathrm{I}_{\mathrm{U}}=\mathrm{PR}_{\mathrm{L}} \cdot \mathrm{s}_{\mathrm{L}}$ (which equals: $\mathrm{I}_{\mathrm{U}}=\mathrm{PR}_{\mathrm{L}} \alpha \mathrm{S}_{\mathrm{L}}$ ) in acquiring shares (ii) he consumes the remainder

$$
\mathrm{C}_{\mathrm{L}}=\left(1-\mathrm{PR}_{\mathrm{L}}\right) \alpha \mathrm{S}_{\mathrm{L}} \text {. where } \mathrm{s}_{\mathrm{L}}=\mathrm{I}_{\mathrm{U}}+\mathrm{C}_{\mathrm{L}} \text {. }
$$

- (b) Borrowed an additional amount $d=\frac{D}{S_{L}} P R_{L} S_{L}=\frac{D}{S_{L}} P R_{L} \alpha S_{L}=P R_{L} \alpha D$. 
- (c) Acquired an amount $s_{U}=I_{U}+d$ of the shares of the company U. He could so by using the

amount $\mathrm{I}_{\mathrm{U}}$ from the sales of his initial holding and the amount $\mathrm{d}$ from borrowing.

- Third Stage: (the new return): the income of the investor ((i) who holds $s_{U}$ dollars' worth of the shares of the company $\mathrm{U}$ (ii) and who must pay interest of personal debt $\mathrm{d}$ would be:

$$
Y_{U}=\alpha P R_{L}\left[P R_{U} \frac{V_{L}}{V_{U}} X-r D\right]
$$

- Last Stage: Arbitrage profit: Comparing (4) with (3) we obtain:

$$
\Delta Y=Y_{U}-Y_{L}=P R_{L} \alpha X\left[P R_{U} \frac{V_{L}}{V_{U}}-1\right]
$$

Thus, under this approach we can distinguish two situations:

- The first situation: If PRU $=\mathrm{PRL}=1$ then we find the same result as obtained by MM (1958 page 270).

$$
\text { - } \Delta Y=Y_{U}-Y_{L}=\alpha X\left[\frac{V_{L}}{V_{L}-1}\right]
$$

- The Second situation: we can also verify the same result of MM(1958 page 270) without the hypothesis of $\mathrm{PR}_{\mathrm{U}}=\mathrm{PR}_{\mathrm{L}}=1$, we can simply assume $\mathrm{PR}_{\mathrm{U}}=1$, while the payout ratio of the levered firm $\mathrm{PR}_{\mathrm{L}}$ is likely to vary between $0 \%$ and $100 \%$, we get then:

$$
\Delta Y=Y_{U}-Y_{L}=P R_{L} \alpha X\left[\frac{V_{L}}{V_{U}}-1\right]
$$

From equation (7), we conclude that as long $V_{L} \succ V_{U}$ we must verify $Y_{U} \succ Y_{L}$, so that it pays shareholders of corporation $\mathrm{L}$ to sell their investments, by this means decreasing $\mathrm{S}_{\mathrm{L}}$ and hence $\mathrm{V}_{\mathrm{L}}$, and replace them with a mix of consumption and portfolio investment, which contains shares of the unlevered firm and personal debt, thereby growing $\mathrm{S}_{\mathrm{U}}$ and thus $\mathrm{V}_{\mathrm{U}}$. This arbitrage process will be finished when equilibrium restores the stated equalities between the values of the two firms.

* Case 2: we suppose the value of the unlevered firm $V_{U}$, to be larger than that of the Levered one $V_{L}$.

- First stage: The return of the investor who holds $\mathrm{s}_{U}$ dollars of shares of company $U$ representing a fraction $\beta$ of the total outstanding stock $\mathrm{S}_{\mathrm{U}}$. Where $s_{u}=\beta S_{U}$

$$
Y_{U}=\beta P R_{U} X
$$

The return from this portfolio denoted by $\mathrm{Y}_{\mathrm{U}}$ will be a fraction $\beta$ of the income distributed $P R_{U} X$ to shareholders of the unlevered firm U.

- Second stage: suppose that the investor exchanges his initial holding in $U$ by another portfolio in the levered firm L. The arbitrage process with consumption behaviour will take the following form: the investor sold his worth of company U: $s_{u}=\beta S_{U}$ and divided it as follows: $s_{u}=I_{L}+I_{B}+C_{u}$

- (i) He invested partially $I_{L}=P R_{U} \beta S_{U} \frac{S_{L}}{V_{L}}$ of the shares of the company $\mathrm{L}$

- (ii) He invested also $I_{B}=P R_{U} \beta S_{U} \frac{D}{V_{L}}$ of bonds of the company $\mathrm{L}$

- (iii) The remainder will be consumed $C_{U}=\left(1-P R_{U}\right) \beta S_{U}$.

From $\mathrm{I}_{\mathrm{L}}$ and $\mathrm{I}_{\mathrm{B}}$, we can write respectively: $I_{L}=P R_{U} \beta \frac{V_{U}}{V_{L}} S_{L}$ and $I_{B}=P R_{U} \beta \frac{V_{U}}{V_{L}} D$

- Third stage: The return of the investor (i) who holds $\mathrm{I}_{\mathrm{L}}$ dollars worth of the shares of the company $\mathrm{L}$ (ii) and who holds $\mathrm{I}_{\mathrm{B}}$ dollars worth of bonds of the company $\mathrm{L}$. 


$$
Y_{L}=P R_{L} P R_{U} \beta \frac{V_{U}}{V_{L}}(X-r D)+r P R_{U} \beta \frac{V_{U}}{V_{L}} D
$$

- Last stage: Arbitrage profit: comparing $\mathrm{Y}_{\mathrm{L}}$ (from 9) with $\mathrm{Y}_{\mathrm{U}}$ (from 8) we obtain:

$$
\Delta Y=Y_{L}-Y_{U}=P R_{U} \beta X\left[P R_{L} \frac{V_{U}}{V_{L}}-1\right]+P R_{U}\left(1-P R_{L}\right) \beta \frac{V_{U}}{V_{L}} r D
$$

In order to get a profitable arbitrage opportunity for the investor, we must consider a positive difference of returns. Analysing equation (10), we can easily formulate two possibility of payout ratio:

- In the first, if we suppose a full earning model for the two firms $\left(\mathrm{PR}_{\mathrm{L}}=\mathrm{PR}_{\mathrm{U}}=1\right)$, therefore we will obtain the same results as showed by MM(1958) (page 270). According to this situation, equation (10) can be written as:

$$
\Delta Y=Y_{L}-Y_{U}=\beta X\left[\frac{V_{U}}{V_{L}}-1\right]
$$

- In the second, the MM's results can also be obtained if we just assume a full earnings for levered firm $\mathrm{PR}_{\mathrm{L}}=1$ while the payout ratio of the unlevered firm $\mathrm{PR}_{\mathrm{U}}$ is likely to vary between $0 \%$ and $100 \%$ implying that the firm can use a payout policy, which is not restricted to full earnings. Such a representation is written as:

$$
\Delta Y=Y_{L}-Y_{U}=P R_{U} \beta X\left[\frac{V_{U}}{V_{L}}-1\right]
$$

In this context, it is also important to show that as $V_{U} \succ V_{L}$ we must obtain $Y_{L} \succ Y_{U}$, hence it pays the shareholders of company $U$ to sell their holdings and substitute them with a mix of consumption and portfolio investment, which contains shares and bonds. If $V_{U} \succ V_{L}$, all investors in firm $\mathrm{U}$ will accomplish the three stages below, decrease the value of the unlevered firm $U$ and increase the price of the levered firm L. This switching process will be over when equilibrium restores the stated equalities between the values of the two firms.

From these demonstrations (case 1 and case 2) we can conclude that we are not compelled to suppose that the two firms distribute all of their returns. In other words we can make arbitrage process merely by considering that the overpriced firm (levered firm $\mathrm{L}$ in the first case and unlevered firm $\mathrm{U}$ in the second case) has a payout ratio PR which is not restricted to be $100 \%$ of the earnings.

\section{The Empirical Analysis}

The previous part of this paper provides a new extension of the relationship between firm value and capital structure when the firm has a payout policy. In this section, we attempt some possible empirical tests. The central issue is, whether or not the leverage ratio affects firm value when earnings are not fully distributed?

Modigliani and Miller (1958) have taken two samples of 43 electric utilities during 1947-1948 and 42 oil companies during 1953. The data are provided respectively by two studies conducted by Allen (1954) and Smith (1955); and they estimated the weighted average cost of capital (wacc) according to the financial leverage of the firm. The regression form of the model was:

$$
W A C C=a_{0}+a_{1} \text { Leverage }+\varepsilon
$$

Where wacc is the weight cost of capital approximated by $X / V$, here $X$ is the expected return net of taxes, $\mathrm{V}$ is the market value of all securities and the financial leverage of the firm measured by the ratio $D / V$, where $D$ is the market value of Bonds and preferred stock. The results of the tests (as shown MM (1958page 282) are favourable to Modigliani and Miller (1958)'s hypothesis. The values of the correlations coefficients are small and not statistically significant. Weston (1963) criticizes Modigliani-Miller empirical result. In particular, he assumes that the lack of effect of capital structure on the overall value of the firm is due to deficiency of the approach to take account of other factors that may be influencing the firm's cost of capital. Contrary to MM, the author shows in the empirical tests that leverage is correlated negatively with firm value in the presence of the hypothesis of earnings growth. 


\subsection{Data and Methodology}

In order to conduct an empirical analysis similar to MM's, we have collected data on the same sectors from the same country as done by Modigliani and Miller 1958. The data we use are annual standardized financial information of US firms observed in the period 1990-1998. Our sample is formed by two sub samples: from the Electric sector we use 256 companies, and from the oil sector we take 223 companies. These data were obtained from the Worldscope Database (SIC Code 13 and 49). Contrary to Weston (1963), we consider the hypothesis of risk-class can be verified in the oil industry and the electric sector (as supposed by MM 1958).

According to MM (1958), a linear model was constructed to explain the relationship between leverage and the firm value. The variables used in our regressions are constructed (see Table 2) as the same way as presented by these authors. The corresponding models used by MM(1958) are: For Model 1 :see MM(1958) page284 (note 38), for model 2,see MM(1958) page282; For Model 3,see MM(1958) page284 (note 39). With regard to the basic capital structure irrelevance theorem to be estimated; we propose three regressions models as follows:

$$
\begin{array}{r}
\text { Model 1: } \text { Value }_{i j}=f+g E R_{i j}+h D R_{i j}+v_{i j} \\
\text { Model 2: } \text { WACC }_{i j}=a+b \text { Leverage }_{i j}+\varepsilon_{i j} \\
\text { Model 3: } \text { WACC }_{i j}=c+d \text { Leverage }_{i j}+e M L 1_{i j}+u_{i j}
\end{array}
$$

Where wacc is the weighted average cost of capital; Leverage 1: first measure of leverage; ML1: modified leverage 1; Value: the ratio of the firm value; ER: earnings ratio; DR debt ratio.

The purpose of model 1 is to test the effect of leverage (as measured by Debt ratio DR) on firm value, while the Model 2 and model 3 test the effect of leverage (measured by Leverage1) on the cost of capital (measured by WACC). The variable ML1 (modified leverage 1) is included in model3 to test the U-shaped hypothesis that the coefficient $\mathrm{e}$ of this variable should be significant and positive to confirm the traditional view, and not significantly different from zero to confirm the irrelevance theorem. Note also that according to our approach the correlation between these variables should be different from zero.

To test the validity of the MM's proposition when earnings are not fully distributed, we alternatively estimate all the above regressions in the absence (model MM58 and the model MM58supp) and the presence of the payout ratio. We validate this last alternative in two steps: In the first step, we test the models for all firms (model $M M E x t)$. In the second step, we test the models for subsamples: First Quartile sample (Firm's Payout ratio is less than 25\%), Second Quartile sample (firm's payout ratio is between 25\% and 50\%), Third Quartile sample (firm's payout ratio is between $50 \%$ and $75 \%$ ), and Fourth Quartile sample (firm's payout ratio is more than $75 \%$ ). The Table 2 below reports the different measures of variables and their predicted effects.

\section{[Insert Table 2 here]}

\subsection{Descriptive statistics}

As indicated in Table 3, the descriptive statistics shows that the average value of cost of capital is $5.92 \%$ for electric utilities and $4.48 \%$ for oil companies (note 2). On average, we have a leverage ratio of $51.79 \%(37.85 \%)$, this measure is $62 \%(50.2 \%)$ when we use total assets as deflator. The average firm has a value ratio of 1,38 for electric utilities which is much weaker than those of oil companies $(1,99)$. For these firms, earnings ratio ranges from $0 \%$ to $2.7 \%$ for electric utilities ( $0 \%$ to $66 \%$ for oil companies). In terms of net income, the average value of payout is more important for electric utilities (45\%) ranging from $0 \%$ to $99,9 \%$, than those of oil companies $(16 \%)$. These results show that the division of the stream between cash dividend and retained earnings in any period is not a mere detail as supposed by Modigliani and Miller (1958 page 266). None of firms in the two samples and during the whole period (1990-1998) has distributed the totality of its income. For the normal distribution of the series around the mean (see table 3), all of the distributions of the variables are not symmetric since their skewness values are different from zero. This conclusion is also verified by the values of the Kurtosis which are quite different from 3.

[Insert Table 3 here]

\subsection{Test of the effect of Leverage on the firm value (model 1)}

The MM (1958)'s theorem is confronted with our hypothesis in order to know the crucial effect of payout ratio on the sensitivity of firm value to leverage. If our prediction is true, we should find a significant coefficient of leverage ratio, otherwise the MM's view should be confirmed. As indicated in Table 4, estimates result shows that coefficients of earning ratio (ER) and debt ratio (DR) are significantly different from zero, which fails to support the MM's view. Since our results, as presented below, demonstrate that the coefficient of debt ratio is significantly negative and contrary to the traditional view. We prefer to give more clarifications of this 
relationship based on the presence of the payout policy. The latter has a negative influence on the two samples (see Model MMExt, Table 4) which is in the opposite direction as obtained by the cost of capital regressions (see table5). There are two main explanations for this result: (1) According to Brigham and Gordon (1968), the relationship between stock price and leverage depends on the association between $\mathrm{R}$ (return on assets and investment) and $\mathrm{i}$ ( the rate of interest which the firm pays on its debt), not on the level of Leverage L. when $\mathrm{R}$ is less than $i$, the leverage effect on stock price $P$ will be negative. Furthermore, the negative influence of the dividend ratio on the firm value confirms the leverage impact when the return on investment is less than the cost of debt. This means that firms experiencing lower rate of investment tend to use funds from internal and external resources to display higher payout ratio. (2) The leverage measure is not the same: in Wacc regression, this variable is measured by debt on firm value $(\mathrm{D} / \mathrm{V})$, while in firm value regression (Value), the debt ratio is measured by debt on total Assets (D/A). The fact that both variables are divided by differents deflators may be affected by a random disturbances of the market value of the firm. This bias correlation is not observed in the firm value regression.

According to Modigliani and Miller (1958), the constant term in the previous regression should give more information on the value of the unlevered firm. As shown in Table 4 below, the estimated coefficient of this variable is not only significantly different from zero, but is quite positive and greatly relative to the coefficient of the debt ratio. This conclusion is confirmed for the two samples with large values for the oil companies.

\section{[Insert Table 4 here]}

\subsection{Test of the effect of leverage on the cost of capital (model 2 and Model 3)}

According to Modigliani and Miller's proposition I: "the average cost of capital Wacc ( $\left.\mathrm{X}^{\mathrm{t}} / \mathrm{V}\right)$ should tend to have the same value independently of the degree of leverage" MM (1958, page281). In other words, the leverage's coefficient parameter in the Wacc regression should be insignificant and statistically equal to zero. The results of the MM model tests are shown in table 5 (models: MM58 and MM58supp). According to this table, the MM hypothesis is only verified in the oil sample, while leverage in the electric utilities has a negative and significant effect (coefficient is equal $-0,1162$ ) on the cost of capital. In accordance with MM model, the fact of adding another measure in the WACC regression (ML1 in MM58supp)) is clearly favourable to MM hypothesis. The coefficients of leverage 1 in the two samples are close to zero and not significant(- -0.056 for electric sample and 0.021 for oil firms). While, the modified leverage ML1 is significant and negatively correlated with the cost of capital (respectively -0.013 and -0.009 for electric and oil firms). This result is the same as obtained by Modigliani and Miller (1958 page 284 note 39) where they interpret it as the reverse of the traditional view.

When we introduce the hypothesis of payout as not fully distributed in the previous analysis, the correlation between leverage 1 and the cost of capital is significantly negative and quite different from zero (The results of these tests are shown in table5, see Model MMExt,). This result is consistent with our hypothesis (we expect a significant influence of leverage on the cost of capital) and contradicts the validity of the irrelevance theorem. Furthermore, this result is confirmed in six out of eight tests conducted on the sub-samples: First Quartile, Second Quartile, Third Quartile and FourthQuartile.

Unlike Modigliani and Miller (1958), dividend policy is an important factor that explains the relationship between leverage and the firm's cost of capital. The estimations provide evidence for a decreasing cost of capital as the leverage ratio increases. It is significant to note also that according to Modigliani and Miller (1958), the constant terms of the regressions equations are measures of the cost of capital of Unlevered firms in the same risk-class. The estimates for the electric utilities and oil companies show that these costs are close to an accepted critical rate.

Additional tests were also conducted to assess the relevance of the variable ML1, which is supposed to take into account the curvilinear effect of the leverage on the cost of capital. Our results suggest (table 5) that the U-shaped relationship between these variables is not observed and the data provide no evidence of the traditional view. Although the variable ML1 has the same sign as indicated by MM(1958 page 284), the tests show that for both industries the coefficients are significantly different from zero.

\section{[Insert Table 5 here]}

According to our results (see table 5), when dividend payout ratio is different from $100 \%$, the cost of capital (wacc) should vary significantly with the ratio of financial structure as measured by $\mathrm{D} / \mathrm{V}$. This relationship tends to be linear and with negative (or positive) slope. The analysis of the evolution of the debt ratio coefficient for each level of payout shows that the company should not remain indifferent to the choice of financial structure (Table 5). Based on the firm's payout policy, it is possible to minimize the cost of capital through a judicious 
adjustment of capital structure. The results of the estimations of these variables show that the company can borrow (both sectors) when the payout is low (PYR $<0.25$ ) or High (PYR $>0.75$ ), while a moderate policy of dividend $(0.5<\mathrm{PYR}<0.75)$ leads us to analyze the risk of the firm. In fact, when firm's risk is low (like electric utilities), financing projects with debt is advantageous for shareholder wealth. However, if the level of risk is higher (like oil companies), borrowing is not beneficial and the firm should seek another cheaper financial instrument than debt.

In addition to the previous theoretical and empirical results, it is possible to summarize our findings as showed by Table 6 . This Table also compares our approach (partial payout model) with the MM's capital structure irrelevance model (full payout model).

[Insert Table 6 here]

\section{Concluding Remarks}

This paper has provided theoretical and empirical evidence of the importance of payout policy in explaining the relationship between leverage and the firm value. MM's capital structure irrelevance theorem implicitly and artificially uses the assumption 100\% FCF payout, thereby forcing firms to consider only among payout ratios which distribute all the income available for the stockholders in every period. This constraint means that shareholders are indifferent towards dividends and retained earnings and leads to the absurd conclusion that common stock must always sell at book value.

The theoretical part of the paper constitutes a new extended proof of the MM theorem by relaxing the hypothesis of earnings as fully distributed. We have shown that it is possible to verify the theorem when we suppose an investor who exchanges his initial holding by a mix of consumption and investment in another portfolio. The proof shows that we are not compelled to suppose that the two firms distribute all of their returns. As a consequence, we can make an arbitrage process merely by considering that unlevered (or levered) firm has such payout ratio.

In the empirical analysis, the paper tested the MM theorem after allowing earnings as not fully distributed. Estimates results show a correlation coefficient between firm value and leverage statistically significant, different from zero and fails to support the MM's view. The downward sloping part of the linear relationship between the cost of capital and leverage depends on the level of the payout ratio adopted by the firm.

The limitations of this study should again be emphasised. In the empirical analysis, we did not rely on variables related to market imperfections to test the robustness of our results, but simply proposed a model to test the validity of the MM's view and to show the importance of the payout policy in resolving the capital structure puzzle. Still, we believe that our approach may give some useful ideas for further research. As MM(1958 page 296) conclude " having served their purpose they can now be relaxed in the direction of greater realism and relevance, a task in which we hope others interested in this area will wish to share".

\section{References}

Allen, F.B. (1954). Does Going into Debt Lower the Cost of Capital? Analysts Journal, vol X, August 1954, 57-61. http://dx.doi.org/10.2469/faj.v10.n4.57

Bailey, R. E. (2010). Corporate Finance: the Modigliani-Miller Theorems. [Online] Available: http:// courses.essex.ac.uk/ec/ec372/lecture-notes/Modigliani_miller-note.pdf

Brigham E.F and Gordon M.J. (1968). Leverage, Dividend policy, and the cost of capital. The Journal of Finance, vol 23, N1, 1968, 85-103. http://dx.doi.org/10.2307/2325311

Chang, K..P. (2004). A Reconsidering of the Modigliani-Miller Proposition. [Online] Available: http://papers.ssrn. Com/sol3/papers.cfm?abstract id $=657921$..

Durand D. (1952). Cost of Debt and Equity funds for Business: trends and Problems of measurement. In conference on Research in Business Finance, New York: NBER 1952, 215-247. [Online] Available: http://www.nber.org/chapters/c4790.pdf

DeAngelo, H., and DeAngelo, L. (2006). The irrelevance of the MM Dividend irrelevance theorem. Journal of Financial Economics, 79, 293-315. http://dx.doi.org/10.1016/j.jfineco.2005.03.003.

Fisher, I. (1930). The theory of interest: as determined by impatience to spend income and opportunity to invest it. New York: Macmillan.

Gordon, M. J., and Chamberlin, T. (1994). "Neoclassical Theory on Capital Structure" in Finance, Investment and macroeconomics edited by M.J Gordon (1994), chapter 4, 47-58. 
Modigliani, F. (1989). MM-Past, Present, Future. Journal of Economic Perspectives, 1989, 149-158. [Online] Available: http://ideas.repec.org/a/aea/jecper/v2y1988i4p149-58.html

Modigliani, F., and Miller, M. (1958). The Cost of capital corporation Finance and The theory of Investment. American Economic review, June 1958, 261-97. [Online] Available: http://bbs.cenet.org.cn/uploadlmages/200351010534890199.pdf

Morton, W.A. (1954). The Structure of the capital market and the price of Money. American Economic Review, 44, No2 (May 1954), 440-454. [Online] Available: http://www.jstor.org/stable/1818357

Myers S. (1984). The capital structure puzzle. Journal of finance, July 1984, 575-92. http://dx.doi.org/10.2307/2327916

Rajan R and L Zingales. (1995). What do we know about capital structure? Some evidence from international data. The Journal of Finance, December 1995, 1421-60. http://dx.doi.org/10.2307/2329322.

Ross, S. (1988). Comment on the Modigliani-Miller propositions. Journal of Economic perspectives, vol 2, 127-133. [Online] Available: http://www.rose-hulman.edu/ bremmer/EMGT/paper/ross.pdf

Rubinstein, M. (2003). Great Moments in Financial Economics: II.. Modigliani-Miller theorem. Journal of Investment Management, Spring, 1(2), 7-13. [Online] Available: http://papers.ssrn.com/sol3/papers.cfm?abstract_id $=495823$

Smith, R. (1955). Cost of capital in the oil Industry. Carnege Institute of Technology, (cited in Modigliani F and M Miller 1958 p281).

Stigliz, J. (1988). Why Financial Structure Matters. Journal of Economic perspectives, vol2, fall 1988, 121-126. [Online]Available: http://www.rose-hulman.edu/ bremmer/EMGT/stiglitz_2.pdf

Stulz, R.M. (2006). "Merton Miller" working paper prepared for the new Palgrave Dictionary. Ohio State University, Charles A.dice center for research in Finance Economics. [Online] Available: http://www.cob.ohio-state.edu/fin/dice/papers/2006/2006-4.pdf

Weston, J.F. (1963). A Test of Cost of Capital Proposition. Southern Economic Journal, vol 30, N2, October 1963, 105-112. http://dx.doi.org/10.2307/1055958

Williams, J.B. (1938). The theory of investment value (Cambridge, MA: Harrvard University Press, 1938); reprinted (Burlington, VT: Faster Publishing, 1997).

\section{Notes}

Note 1. As Modigliani (1989) notes «The MM paper is unquestionably the most popular of my writings, primarily because it has been, and continues to be, required reading for many graduate business schools. » Modigliani.F (1989) p149-158.

Note 2. As DeAngelo and DeAngelo(2006, page 294) wrote “ When MM's assumptions are modified to allow retention with the NPV of Investment policy fixed, a firm can reduce its value by paying out less than the full present value of FCF, and so Payout policy matters and Investment policy is not the sole determinant of value ".

Note 3. The extreme values (very low or very high) obtained from descriptive statistics are due to the proxy used in the study. According to MM (1958), we have measured the cost of capital by dividing earnings on the firm value. 
Table 1. The irrelevance of the MM capital structure irrelevance when payout ratio is different from $100 \%$

\begin{tabular}{|c|c|c|}
\hline & First possibility : $V_{L}>V_{U}$ & Second possibility $: V_{U}>V_{L}$ \\
\hline $\begin{array}{l}\text { First stage the initial } \\
\text { return of the investor } \\
\qquad \mathrm{Y}_{\mathrm{L}}\end{array}$ & $Y_{L}=a P R_{L}(X-r D)$ & $Y_{U}=a P R_{U} X$ \\
\hline $\begin{array}{l}\text { Second Stage: } \\
\text { Arbitrage process }\end{array}$ & $\begin{array}{l}\text { - Sold his initial worth of the firm } \mathrm{L} \\
\text { - Borrows an additional amount } d_{L} \text { with } \\
\text { the same interest rate } r \\
\text { - Acquired new shares of the firm u }\end{array}$ & $\begin{array}{l}\text { sold his initial worth of the firm } U \\
\text { Acquired new shares of the firm } L \\
\text { Acquired new bonds b of the firm } L\end{array}$ \\
\hline $\begin{array}{l}\text { Third stage: the return } \\
\text { of the investor } Y_{U}\end{array}$ & $\begin{array}{l}Y_{U}=\frac{\left(s_{L}+d_{L}\right)}{S_{U}} P R_{U} X-r d_{L} \\
=\frac{a V_{L}}{V_{U}} P R_{U} X-r a D\end{array}$ & $\begin{aligned} Y_{L} & =\frac{s_{L}}{S_{L}} P R_{L}(X-r D)+b \\
& =a \frac{V_{U}}{V_{L}} P R_{L}(X-r D)+a \frac{V_{U}}{V_{L}} r D\end{aligned}$ \\
\hline $\begin{array}{l}\text { Final stage: } \\
\text { Difference of earnings } \\
\qquad \Delta \mathrm{Y}=\mathrm{Y}_{\mathrm{U}}-\mathrm{Y}_{\mathrm{L}}\end{array}$ & $\begin{aligned} Y_{U}-Y_{L}= & a X\left[P R_{U} \frac{V_{L}}{V_{U}}-P R_{L}\right] \\
& +r a D\left[P R_{L}-1\right]\end{aligned}$ & $\begin{aligned} Y_{L}-Y_{U}= & a X\left[P R_{L} \frac{V_{U}}{V_{L}}-P R_{U}\right] \\
& +a \frac{V_{U}}{V_{L}} r D\left[P R_{L}-1\right]\end{aligned}$ \\
\hline Interpretations & \multicolumn{2}{|c|}{$\begin{array}{l}\text { It is not possible to verify the MM results when we introduce the hypothesis of payout ratio } \\
\text { different from } 100 \% \text {, the difference of returns will depend on the all components of the } \\
\text { equation. When we pose } \mathrm{PR}_{\mathrm{L}}=\mathrm{PR}_{\mathrm{U}}=1 \text {, it is easy to obtain the same difference of returns as } \\
\qquad \mathrm{MM}(1958) \text { : }\end{array}$} \\
\hline $\begin{array}{l}\text { Using the MM formula } \\
\text { Company } U \text { is financed } \\
\text { then } V_{U}=S_{U} \text { and } V_{L}= \\
1958 \text { suppose } P R_{L}=P l \\
\text { owned respectively by }\end{array}$ & $\begin{array}{l}\text { 1, we consider two firms } \mathrm{L} \text { and } \mathrm{U} \text {, for whi } \\
\text { irely by stock } \mathrm{S}_{\mathrm{U}} \text { and company } \mathrm{L} \text { by stock } \\
+\mathrm{D} \text {, We denote } \mathrm{PR}_{\mathrm{L}} \text { and } \mathrm{PR}_{\mathrm{U}} \text { the payou } \\
=100 \% \text { all expected return is distributed). } \\
\text { nvestor in the levered and unlevered firm }\end{array}$ & $\begin{array}{l}\text { the expected return is the same } \mathrm{X}_{\mathrm{L}}=\mathrm{X}_{\mathrm{U}}=\mathrm{X} \text {. } \\
\mathrm{S}_{\mathrm{L}} \text { and debt } \mathrm{D} \text {. The market value of each firm is } \\
\text { ratios of the levered and unlevered firms (MM } \\
\mathrm{L}=\alpha \mathrm{S}_{\mathrm{L}}, \mathrm{s}_{\mathrm{U}}=\alpha \mathrm{S}_{\mathrm{U}} \text { denote the value of shares } \\
\text { ith a fraction } \alpha\end{array}$ \\
\hline
\end{tabular}

Table 2. Measures of variables and predicted signs

\begin{tabular}{|c|c|c|c|c|}
\hline Variables & Symbol & Measure & MM Hypothesis & Our Hypothesis \\
\hline \multicolumn{5}{|l|}{ Dependants variables } \\
\hline $\begin{array}{l}\text { - Weighted average cost of } \\
\text { capital }\end{array}$ & $W A C C$ & $X / V$ & & \\
\hline - $\quad$ Firm value ratio & Value & $V / A$ & & \\
\hline \multicolumn{5}{|l|}{ The explanatory variables } \\
\hline First measure of leverage & Leverage 1 & $D / V$ & Zero effect & Significant effect \\
\hline Modified Leverage 1 measure & $M L 1$ & $D . D / V . S$ & Zero effect & Significant effect \\
\hline Earnings ratio & $E R$ & $X / A$ & & \\
\hline Debt ratio & $D R$ & $D / A$ & Zero effect & Significant effect \\
\hline Payout ratio & Payout & Div/NI & Not tested & Significant effect \\
\hline
\end{tabular}


Table 3. Descriptive Statistics of Variables (256 Electric Utilities and 223 Oil Companies)

\begin{tabular}{|lllllllll|}
\hline Variables & Sample & Mean & Minimum & Maximum & Std. Dev & Skewness & Kurtosis & Obs \\
\hline WACC & Elect & 0.05924 & 0.00000 & 0.29090 & 0.03188 & 0.292328 & 6.376099 & 2304 \\
& Oil & 0.04481 & 0.00000 & 0.69582 & 0.05448 & 4.75993 & 42.0526 & 2007 \\
Leverage1 & Elect & 0.51796 & 0.01573 & 0.99416 & 0.17873 & -0.46925 & 3.36365 & 2304 \\
& Oil & 0.37857 & 0.0000 & 0.98237 & 0.21714 & 0.20952 & 2.36431 & 2007 \\
Value & Elect & 1.38155 & 0.09087 & 9.77112 & 0.82268 & 5.51989 & 45.7871 & 2304 \\
& Oil & 1.99172 & 0.14447 & 138.56 & 5.40308 & 18.7716 & 397.615 & 2006 \\
ER & Elect & 0.07353 & 0.0000 & 0.027612 & 0.04158 & 0.77790 & 7.94274 & 2304 \\
& Oil & 0.06418 & 0.0000 & 0.664303 & 0.06683 & 2.104262 & 11.546 & 2007 \\
DR & Elect & 0.62322 & 0.02761 & 0.995066 & 0.14891 & -0.9991 & 4.78983 & 2304 \\
& Oil & 0.50220 & 0.0000 & 0.9978 & 0.22065 & -0.2593 & 2.4847 & 2006 \\
ML1 & Elect & 1.34913 & 0.000252 & 169.346 & 6.6480 & 17.3645 & 344.950 & 2304 \\
& Oil & 0.61298 & 0.0000 & 23.2454 & 1.5346 & 8.6309 & 103.96 & 2006 \\
Payout & Elect & 0.45169 & 0.00000 & 0.99980 & 0.35978 & -0.15569 & 1.40417 & 2304 \\
& Oil & 0.16381 & 0.0000 & 0.9991 & 0.27721 & 1.50967 & 3.90646 & 2006 \\
\hline
\end{tabular}

Table 4. Directs Pooled Least-Squares Estimates of the effects of leverage on the firm value

$$
\text { Value }_{i j}=f+g E R_{i j}+h D R_{i j}+v_{i j}
$$

\begin{tabular}{|llcccccc|}
\hline \multirow{2}{*}{ Regressions } & Sample & Constant & ER & DR & Payout & AdR & Obs \\
\hline MM 58 & Elect & $1.893^{\mathrm{a}}$ & $-0.158^{\mathrm{a}}$ & $-0.805^{\mathrm{a}}$ & - & 0.025 & 2304 \\
& Oil & $2.464^{\mathrm{a}}$ & $-6.730^{\mathrm{a}}$ & -0.668 & - & 0.048 & 2007 \\
\hline MM Ext & Elect & $1.963^{\mathrm{a}}$ & $-0.131^{\mathrm{a}}$ & $-0.466^{\mathrm{a}}$ & $-0.625^{\mathrm{a}}$ & 0.095 & 2304 \\
& Oil & $2.465^{\mathrm{a}}$ & $-6.703^{\mathrm{a}}$ & -0.642 & -0.086 & 0.048 & 2007 \\
\hline \multirow{2}{*}{ First Quartile } & Elect & $1.969^{\mathrm{a}}$ & $-0.133^{\mathrm{b}}$ & $-0.412^{\mathrm{c}}$ & - & 0.005 & 801 \\
& Oil & $2.342^{\mathrm{a}}$ & $-7.490^{\mathrm{a}}$ & -0.286 & - & 0.052 & 1440 \\
\hline \multirow{2}{*}{ Second Quartile } & Elect & $1.465^{\mathrm{a}}$ & $2.650^{\mathrm{a}}$ & $-0.554^{\mathrm{a}}$ & - & 0.187 & 216 \\
& Oil & $1.659^{\mathrm{a}}$ & -0.197 & $-0.501^{\mathrm{a}}$ & - & 0.033 & 279 \\
\hline Third Quartile & Elect & $1.206^{\mathrm{a}}$ & $1.823^{\mathrm{a}}$ & $-0.249^{\mathrm{a}}$ & - & 0.096 & 738 \\
& Oil & $1.224^{\mathrm{a}}$ & $3.229^{\mathrm{a}}$ & -0.055 & - & 0.113 & 207 \\
\hline Fourth Quartile & Elect & $1.080^{\mathrm{a}}$ & $1.809^{\mathrm{a}}$ & -0.105 & - & 0.102 & 549 \\
& Oil & $7.197^{\mathrm{a}}$ & 0.983 & $-9.064^{\mathrm{a}}$ & - & 0.676 & 72 \\
\multirow{2}{*}{ a, b and c indicate } & significance at the $1 \%, 5 \%$, and $10 \%$ levels respectively. & & & \\
\hline
\end{tabular}


Table 5. Directs Pooled Least-Squares Estimates of the effects of leverage on the cost of capital

$$
w a c c_{i j}=c+d L \text { everage } 1_{i j}+e M L 1_{i j}+u_{i j}
$$

\begin{tabular}{|lccccccc|}
\hline \multicolumn{1}{|c}{ Regressions } & Sample & Constant & Leverage1 & ML1 & Payout & Adj. ${ }^{2}$ & Obs \\
\hline MM 58(model1) & Elect & $0.117^{\mathrm{a}}$ & $-0.116^{\mathrm{a}}$ & - & - & 0.006 & 2304 \\
& Oil & $0.020^{\mathrm{a}}$ & -0.018 & - & - & 0.0003 & 2007 \\
\hline MM 58 Supp(model 2) & Elect & $0.098^{\mathrm{a}}$ & -0.056 & $-0.013^{\mathrm{b}}$ & - & 0.007 & 2304 \\
& Oil & 0.011 & 0.021 & $-0.009^{\mathrm{a}}$ & - & 0.007 & 2007 \\
\hline MM Ext (model 1with & Elect & $0.111^{\mathrm{a}}$ & $-0.156^{\mathrm{a}}$ & - & $0.059^{\mathrm{a}}$ & 0.012 & 2304 \\
dividend payout ratio) & Oil & $0.014^{\mathrm{a}}$ & $-0.050^{\mathrm{a}}$ & - & $0.107^{\mathrm{a}}$ & 0.042 & 2007 \\
\hline First Quartile & Elect & $0.142^{\mathrm{a}}$ & $-0.236^{\mathrm{a}}$ & - & - & 0.014 & 801 \\
& Oil & $0.019^{\mathrm{a}}$ & $-0.064^{\mathrm{a}}$ & - & - & 0.008 & 1440 \\
\hline Second Quartile & Elect & $0.053^{\mathrm{a}}$ & 0.006 & - & - & 0.001 & 216 \\
& Oil & 0.003 & $0.110^{\mathrm{a}}$ & - & - & 0.033 & 279 \\
\hline Third Quartile & Elect & $0.083^{\mathrm{a}}$ & $-0.026^{\mathrm{a}}$ & - & - & 0.012 & 738 \\
& Oil & $0.045^{\mathrm{a}}$ & 0.018 & - & - & 0.002 & 207 \\
\hline Fourth Quartile & Elect & $0.093^{\mathrm{a}}$ & $-0.038^{\mathrm{a}}$ & - & - & 0.031 & 549 \\
& Oil & $0.136^{\mathrm{a}}$ & $-0.196^{\mathrm{b}}$ & - & - & 0.052 & 72 \\
& & & & & & \\
a, b, and c indicate significance at the $1 \%, 5 \%$, and $10 \%$ levels respectively. & & & \\
\hline
\end{tabular}

Table 6. Capital structure irrelevance theorem: Full versus Partial payout Models

\begin{tabular}{|lll|}
\hline & \multicolumn{1}{c|}{$\begin{array}{c}\text { Irrelevance Model MM(1958) : } \\
\text { (Full Payout Model) }\end{array}$} & \multicolumn{1}{c|}{$\begin{array}{c}\text { Our Extension of MM's Model: } \\
\text { (Partial Payout Model) }\end{array}$} \\
\hline Main conclusion & $\begin{array}{l}\text { Capital structure is irrelevant only with a } \\
\text { full payout ratio condition. }\end{array}$ & $\begin{array}{l}\text { Pay-out ratio plays a crucial effect in } \\
\text { explaining the relationship between } \\
\text { capital structure and firm value. }\end{array}$ \\
\hline $\begin{array}{l}\text { Key Assumption for capital } \\
\text { structure Analysis }\end{array}$ & $\begin{array}{l}\text { Arbitrage model with perfect market } \\
\text { conditions. }\end{array}$ & $\begin{array}{l}\text { Arbitrage model with perfect market } \\
\text { conditions. }\end{array}$ \\
\hline Implied restrictions & $\begin{array}{l}\text { Firm is restricted to choose among payout } \\
\text { policies that which distributes all feasible } \\
\text { earning. }\end{array}$ & $\begin{array}{l}\text { Firm is not compelled to distribute all } \\
\text { earnings as dividends. }\end{array}$ \\
\hline $\begin{array}{l}\text { Characteristics of capital } \\
\text { structure Analysis }\end{array}$ & $\begin{array}{l}\text { - Investment in shares and Bonds. } \\
\text { - Borrowing }\end{array}$ & $\begin{array}{l}\text { - Investment in shares and Bonds. } \\
\text { - Borrowing } \\
\text { - Consumption }\end{array}$ \\
\hline Empirical tests and results & $\begin{array}{l}\text { Correlation between firm value and } \\
\text { leverage is not significantly different from } \\
\text { zero }\end{array}$ & $\begin{array}{l}\text { Correlation coefficient between firm } \\
\text { value and leverage is statistically } \\
\text { significant }\end{array}$ \\
\hline
\end{tabular}

